\title{
Evolution of Haptoglobin Concentration in Serum during the Early Phase of Acute Myocardial Infarction
}

\author{
Dirk R. Bernard, Michel R. Langlois, Joris R. Delanghe and Marc L. De Buyzere
}

Laboratorium Klinische Scheikunde, Universitair Ziekenhuis Gent, Gent, Belgium

Summary: Haptoglobin (Hp) is a haemoglobin-binding acute phase protein with three genetic types: Hp 1-1, Hp 2-1, Hp 2-2. We investigated 45 patients during the first 48 hours of acute myocardial infarction, and studied determinant factors and clinical correlates. Upon hospital admission, serum haptoglobin concentration was increased $(1.95 \pm 0.94 \mathrm{~g} / 1$, mean $\pm \mathrm{SD}, \mathrm{P}<0.001)$ versus the reference population $(0.97 \pm 0.46 \mathrm{~g} / \mathrm{l}, \mathrm{n}=107)$, independent of haptoglobin type: $1.84 \pm 0.64 \mathrm{~g} / \mathrm{l}(\mathrm{Hp} \mathrm{1-1,} \mathrm{n}=11)(\mathrm{P}<0.01), 1.98 \pm 0.79 \mathrm{~g} / 1(\mathrm{Hp} \mathrm{2-1,} \mathrm{n}=25)(\mathrm{P}<0.001)$, $1.98 \pm 1.58 \mathrm{~g} / \mathrm{l}(\mathrm{Hp} 2-2, \mathrm{n}=9)(\mathrm{P}<0.001)$. Moreover, during the first hours of hospitalization, a temporal lowering of haptoglobin was observed suggesting acute haemolysis, independent of the haptoglobin type. Minimal serum haptoglobin was reached $9.6 \pm 5.8$ hours after admission. The amplitude of the haptoglobin decrease correlated with initial serum haptoglobin $(r=0.78)$ and was more pronounced $(P<0.05)$ in men $(0.53 \pm 0.57 \mathrm{~g} / \mathrm{l})$ than in women $(0.18 \pm 0.17 \mathrm{~g} / \mathrm{l})$. Decrease of serum haptoglobin did not correlate with infarct size (based on creatine kinase-MB release). Out of the other acute phase proteins measured upon admission, only C-reactive protein was significantly increased $(P<0.05)$. During the next 36 hours, haptoglobin increased as a result of the acute phase response to myocardial injury. Our findings suggest that acute myocardial infarction is also preceded by an acute phase response, characterized by an initial high haptoglobin and followed by a temporal haptoglobin decrease due to haemolysis.

\section{Introduction}

Atherogenesis and acute myocardial infarction are known to be associated with inflammation (1) and limited haemolysis. As haptoglobin $(\mathrm{Hp})$ is involved both in acute phase reaction (2) and haemolysis (3) we studied the evolution of haptoglobin concentration during the early phase of acute myocardial infarction.

Three genetically determined haptoglobin phenotypes are known: Hp 1-1, Hp 2-1, and Hp 2-2, each with its type-specific reference values $(2,4)$. In the days following acute myocardial infarction, increased haptoglobin concentrations are found, with a maximum about one week after onset of acute myocardial infarction $(5-8)$. In addition to its role as an acute phase reactant, haptoglobin possibly fulfils regulatory functions during acute myocardial infarction (7) such as inhibition of platelet aggregation by crude and highly purified $\alpha_{1^{-}}$ acid-glycoprotein (9). Functional differences between haptoglobin types are known (2). Inhibition of prostaglandin synthesis is type-dependent (2). Haptoglobin polymorphism has been shown to correlate with severity and outcome of acute myocardial infarction (7). The aim of this study was to evaluate haptoglobin concentration during the first 36 hours after onset of acute myocardial infarction, and to study determinant factors and clinical correlates of the observed pattern (haptoglobin type, infarct size, acute phase proteins, ...). Inflammation upon admission was evaluated by measuring the following acute phase proteins; $\alpha_{1}$-acid glycoprotein, $\alpha_{1}$-antiproteinase ( $\alpha_{1}$-antitrypsin), $\alpha_{2}$-macroglobulin and C-reactive protein. As haptoglobin is characterized by a variation of the carbohydrate moiety as well (2), this heterogeneity was also studied.

\section{Materials and Methods}

Study protocol

The study inclusion criterion was the presence of significant Pardee waves (ST elevations of at least $2 \mathrm{~mm}$ in at least 2 adjacent leads) in the electrocardiogram for at least 30 minutes on admission. Diagnosis of acute myocardial infarction was established according to WHO criteria (10). Serum samples from 45 patients admitted because of acute myocardial infarction ( 33 men, age: 58.7 \pm 12.3 years; 12 women, age: $61.6 \pm 12.2$ years; mean $\pm \mathrm{SD}$ ) were analyzed. Healthy blood donors $(n=107$, age: $41 \pm 11$ years) served as a reference population. Blood was sampled upon hospital admission, then every 4 hours until the 16th hour, and further at the 24th, 30th and 36th hour after admission.

\section{Biochemical determinations}

Total creatine kinase ${ }^{1}$ ) activity was measured at $37^{\circ} \mathrm{C}$ according to IFCC (11) with a RA-1000 analyzer (Technicon, Tarrytown, NY, USA), using CK-NAC reagents (J. T. Baker, Deventer, The Netherlands). Creatine kinase-MB isoenzyme activity was measured using immunoprecipitation (Isoimmune-CK ${ }^{\mathrm{TM}}$, Roche, Nutley, NJ, USA) (12). Infarct size was calculated out of cumulative creatine kinaseMB isoenzyme release $(13,14)$. Serum haptoglobin, $\alpha_{1}$-acid glycoprotein, $\alpha_{1}$-antiproteinase, $\alpha_{2}$-macroglobulin, and C-reactive pro-

\footnotetext{
1) Enzymes:

Creatine kinase (EC 2.7.3.2)
} 
tein concentrations were determined with a BN Nephelometer (Behringwerke, Marburg, Germany) (15). Results were expressed according to IFCC standards (16). Haptoglobin typing was carried out according to Smithies (17). Variation in the carbohydrate moiety of haptoglobin were studied by affinity chromatography toward concanavalin A-Sepharose (18).

\section{Statistics}

Results are expressed as mean \pm standard deviation. Haptoglobin type frequencies in the patients and reference group were compared using $\chi^{2}$ testing with Yates' correction. Comparisons between the amplitude of haptoglobin decrease and infarct size and between the amplitude of haptoglobin decrease and initial haptoglobin concentration were made using a Spearman rank correlation test. Results were compared according to haptoglobin type using non-parametric statistics (Kruskal-Wallis). Statistical significance was considered at the level of $\mathrm{P}<0.05$.

\section{Results}

Acute phase protein concentration in acute myocardial infarction upon admission

Upon admission (173 $\pm 68 \mathrm{~min}$ after onset of symptoms, creatine kinase $209 \pm 245 \mathrm{U} / \mathrm{l}$ ), serum haptoglobin concentration in acute myocardial infarction (1.95 \pm 0.94 $\mathrm{g} / \mathrm{l}$ ) was increased compared to the reference population $(0.97 \pm 0.46 \mathrm{~g} / 1 ; \mathrm{P}<0.001)$. Table 1 shows haptoglobin concentrations according to haptoglobin type. For the three haptoglobin types, haptoglobin concentration was significantly higher $(\mathrm{P}<0.01$ for Hp $1-1, \mathrm{P}<0.001$ for Hp 2-1 and Hp 2-2) in acute myocardial infarction compared to the reference population. Type frequencies were 0.24 (Hp 1-1), 0.56 (Hp 2-1) and, 0.20 (Hp 2-2) for acute myocardial infarction patients and 0.20 (Hp 1-1), 0.48 (Hp 2-1) and 0.32 (Hp 2-2) for the reference population (tab. 1). Both distributions were in agreement with the Hardy-Weinberg equilibrium. Haptoglobin type distributions of the reference population and of patients were comparable. Whereas haptoglobin concentration differs between haptoglobin types in the reference population $(p<0.001)$, this difference was not observed in acute myocardial infarction upon admission (tab. 1).

Table 2 shows the concentrations of $\mathrm{C}$-reactive protein, $\alpha_{1}$-acid glycoprotein, $\alpha_{1}$-antiproteinase, $\alpha_{2}$-macroglobu-

Tab. 1 Serum haptoglobin concentration in acute myocardial infarction patients upon admission and in reference population according to haptoglobin phenotype

\begin{tabular}{llllll}
\hline $\begin{array}{l}\text { Haptoglobin } \\
\text { phenotype }\end{array}$ & Reference population & & \multicolumn{2}{l}{$\begin{array}{l}\text { Acute myocardial } \\
\text { infarction patients }\end{array}$} \\
\cline { 2 - 3 } \cline { 5 - 6 } & $\mathrm{n}$ & $\begin{array}{l}\text { Haptoglobin } \\
\text { concentration } \\
(\mathrm{g} / \mathrm{l})\end{array}$ & & $\mathrm{n}$ & $\begin{array}{l}\text { Haptoglobin } \\
\text { concentration } \\
\left(\mathrm{g} / \mathrm{l}^{\mathrm{a}}\right.\end{array}$ \\
\hline Hp 1-1 & 21 & & & & \\
Hp 2-1 & 51 & $0.99 \pm 0.51$ & & 11 & $1.84 \pm 0.41$ \\
Hp 2-2 & 35 & $0.75 \pm 0.42$ & & 25 & $1.98 \pm 0.79^{* *}$ \\
\hline
\end{tabular}

${ }^{\text {a }}$ For acute myocardial infarction patients, serum haptoglobin concentration given upon hospital admission.

$* \mathrm{P}<0.01 ; * * \mathrm{P}<0.001$ compared to the reference population
Tab. 2 Concentration of acute phase proteins in acute myocardial infarction patients upon admission versus reference population

\begin{tabular}{|c|c|c|}
\hline Acute phase protein & $\begin{array}{l}\text { Patients } \\
\text { (mean } \pm \mathrm{SD})\end{array}$ & $\begin{array}{l}\text { Reference } \\
\text { range }^{\mathrm{a}}\end{array}$ \\
\hline C-reactive protein, $\mathrm{mg} / \mathrm{l}$ & $6.4 \pm 4.9 *$ & $<5$ \\
\hline$\alpha_{1}$-Antiproteinase, $\mathrm{g} / \mathrm{l}$ & $1.52 \pm 0.35$ & $1.46 \pm 0.27$ \\
\hline$\alpha_{1}$-Acid glycoprotein, g/l & $1.08 \pm 0.51$ & $0.90 \pm 0.20$ \\
\hline$\alpha_{2}$-Macroglobulin, $\mathrm{g} / \mathrm{l}$ & $2.02 \pm 0.40$ & $1.80 \pm 0.35$ \\
\hline Haptoglobin, $\mathrm{g} / \mathrm{l}$ & $1.95 \pm 0.94 * *$ & $0.97 \pm 0.46$ \\
\hline $\begin{array}{l}\text { Relative concanavalin } \mathrm{A}^{\mathrm{a}} \\
\text { binding of haptoglobin }\end{array}$ & $0.66 \pm 0.19^{*}$ & $0.86 \pm 0.07$ \\
\hline
\end{tabular}

* $\mathrm{P}<0.05, * * \mathrm{P}<0.01$

a Derived from individual data from a reference population measured in our laboratory which took part in a multicentre evaluation program (1.c. (15)).

lin and haptoglobin on admission and compares them with our reference population (15). Only haptoglobin and $\mathrm{C}$-reactive protein were increased compared to the reference population.

\section{Evolution of haptoglobin concentration during acute myocardial infarction}

In acute myocardial infarction, haptoglobin concentrations were serially followed during the first 36 hours after admission (fig. 1). Upon admission, haptoglobin concentration was increased. In the following hours, a temporary lowering of haptoglobin concentration is observed. This initial lowering is followed shortly by a gradual increase of haptoglobin concentration, which is compatible with the role of haptoglobin as an acute phase reactant after acute myocardial infarction. Minimal haptoglobin concentrations were found $9.6 \pm 5.8 \mathrm{~h}$ (range: $2.0-33.0 \mathrm{~h}$ ) after admission. The observed change from admission in haptoglobin concentration was $0.44 \pm 0.52 \mathrm{~g} / 1$ (range $0.03-2.69 \mathrm{~g} / \mathrm{l}$ ) and was comparable among haptoglobin types (tab. 3) and not related to infarct size estimated by creatine kinase-MB isoenzyme release (Spearman $\mathrm{r}=0.17$ ). Significant differences in haptoglobin concentration decrease were observed according to gender. For male patients $(n=33)$, the haptoglobin decrease was $0.53 \pm 0.57 \mathrm{~g} / 1$ vs. 0.18 $\pm 0.17 \mathrm{~g} / 1$ for female patients $(\mathrm{n}=12)(\mathrm{P}<0.05)$. The decrease of haptoglobin concentration correlated with
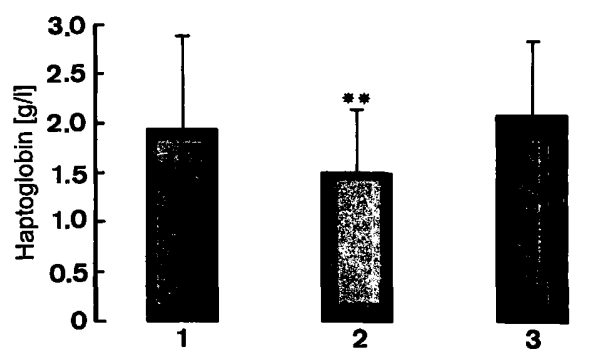

Fig. 1 Evolution of haptoglobin concentration in acute myocardial infarction: at admission (1); at minimal haptoglobin concentration (2); at 24 hours after minimal haptoglobin concentration (3) (** $\mathrm{P}<0.01$, Kruskal-Wallis). 
Tab. 3 Serum haptoglobin decrease and estimated infarct size in acute myocardial infarction patients according to haptoglobin phenotype

\begin{tabular}{lll}
\hline $\begin{array}{l}\text { Haptoglobin } \\
\text { phenotype }\end{array}$ & $\begin{array}{l}\text { Serum haptoglobin } \\
\text { decrease }^{\mathrm{a}}(\mathrm{g} / \mathrm{l})\end{array}$ & $\begin{array}{l}\text { Estimated infarct size } \\
\text { (g creatine kinase- }^{\text {MB equivalent) }}\end{array}$ \\
\hline Hp 1-1 & $0.30 \pm 0.19$ & $26.6 \pm 17.5$ \\
Hp 2-1 & $0.52 \pm 0.24$ & $17.5 \pm 17.0$ \\
Hp 2-2 & $0.56 \pm 0.65$ & $16.2 \pm 13.1$ \\
\hline
\end{tabular}

a Decrease in serum haptoglobin concentration from admission to minimal concentration

b Creatine kinase-MB isoenzyme equivalent (g) (1. c. (14))

haptoglobin concentration upon admission: y (haptoglobin decrease, $\mathrm{g} / 1)=0.43$ (serum haptoglobin upon admission, $\mathrm{g} / \mathrm{l})-0.40 ; \mathrm{r}=0.78, \mathrm{~S}_{\mathrm{xy}}=0.33$.

\section{Microheterogeneity of haptoglobin upon admission}

Concanavalin A affinity chromatography showed that 65 $\pm 19 \%$ of serum haptoglobin in acute myocardial infarction upon admission bound to the lectin (tab. 2). The concanavalin A binding fraction is lower than in the reference population $(86 \pm 7 \%, \mathrm{P}<0.05)$. No differences in concanavalin $\mathrm{A}$ binding according to haptoglobin type were observed.

\section{Discussion}

In the reference population and in acute myocardial infarction patients, the distribution of haptoglobin types corresponds to other European studies (2). Haptoglobin type distribution in both controls and acute myocardial infarction patients was in agreement with the HardyWeinberg equilibrium.

Upon admission, increased haptoglobin concentrations were found in a large majority of acute myocardial infarction patients independently of haptoglobin type. However, haptoglobin concentration in the reference population was significantly lower in $\mathrm{Hp} \mathrm{2-2}$ carriers, which is in accordance to previously published data (2, 4). The observation of a simultaneous increase of haptoglobin and $\mathrm{C}$-reactive protein is in contrast to normal concentrations for $\alpha_{1}$-acid glycoprotein, $\alpha_{1}$-antiproteinase and $\alpha_{2}$-macroglobulin in acute myocardial infarction upon admission and points to a stimulation of haptoglobin and C-reactive protein synthesis prior to the infarction. Haptoglobin and C-reactive protein are acute phase proteins, whose synthesis is stimulated by interleukin- 6 (2). The response of haptoglobin and C-reactive protein synthesis to interleukin-6 stimulation occurs slowly and becomes obvious after $24 \mathrm{~h}$. Our data suggest that acute myocardial infarction is preceded by an acute phase reaction during the day(s) before the coronary thrombosis. This agrees with other studies in which the relationship between infection and inflammatory processes and the risk for acute myocardial infarction was established (1).

The increased serum haptoglobin concentration in acute myocardial infarction upon admission is in agreement with literature $(5-8)$. When comparing haptoglobin values in previous reports $(6,7)$, after conversion to IFCC standards, higher haptoglobin concentrations are found in this study in Hp 2-2 sera, and lower haptoglobin concentrations in Hp 1-1 sera. Relative molecular mass differs between haptoglobin types (Hp 1-1: $M_{\mathrm{r}}=80000$, Hp 2-1: $M_{\mathrm{r}}=120000$, Hp 2-2: $M_{\mathrm{r}}=160000$ ). This leads to different diffusion rates between the haptoglobin types which results in an underestimation of $\mathrm{Hp} \mathrm{2-2}$ concentration with the radial immunodiffusion technique $(2,4,19)$. This might explain the lower Hp 1-1 and higher $\mathrm{Hp}$ 2-2 concentrations determined by nephelometry in this study compared to studies using radial immunodiffusion $(6,7)$.

After admission, a temporary lowering of haptoglobin concentration is found in acute myocardial infarction, which was not reported in previous studies $(5-8)$. The latter is not surprising, as the minimal haptoglobin concentration is observed 9.6 $\pm 5.8 \mathrm{~h}$ after admission and blood samples for haptoglobin determination in the former studies were only collected once daily. In our study the amplitude of the lowering depends on the initial haptoglobin concentration. However, this finding should be viewed with caution. Given a haemolytic pulse as part of the evolution of acute myocardial infarction, the decrease in haptoglobin theoretically might be unrelated to the initial concentration. The initial lowering of haptoglobin concentration following acute myocardial infarction can be explained by haemoglobin-binding. After consumption of haptoglobin, haemopexin levels start to decrease, whereas haptoglobin concentration remains low $(<0.3 \mathrm{~g} / 1)(3)$. In this study, complete consumption of haptoglobin was observed in 2 acute myocardial infarction cases (5\%). Elimination of haemoglobin-haptoglobin complexes by the liver occurs faster because of the rapid recognition by receptors localized at the membrane of liver parenchyma (2). The lowering of haptoglobin during the first hours after admission suggests a moderate acute haemolysis. Based on a haemoglobinhaptoglobin binding ratio of $1: 1$, the observed decrease in haptoglobin concentration corresponds with a haemolysis of $\pm 10 \mathrm{ml}$ erythrocytes, equivalent to a complete haemolysis of $\pm 22 \mathrm{ml}$ of blood. This might be caused by acute changes in red cell survival induced by regional changes of the blood flow (20). Interestingly, our observation of haptoglobin lowering differs significantly according to gender. Rheological properties of whole blood are sex-related: total shear stress of whole blood being lower in females (21). From the second day of hospitalization, the slowly increasing haptoglobin concentration takes part of the acute phase reaction. 
The observed haemolysis has consequences for the estimation of acute myocardial infarction size based on the release of $\alpha$-hydroxybutyrate dehydrogenase (EC 1.1.1.30) (22) since erythrocytes contain considerable amounts of this enzyme. So, the observed haemolysis may cause an overestimation of acute myocardial infarction size when using methods based on release of $\alpha$ hydroxybutyrate dehydrogenase.

The difference in affinity of haptoglobin towards concanavalin A in acute myocardial infarction on admission suggests an altered glycosylation of haptoglobin prior to acute myocardial infarction. Concanavalin A has an affinity towards mannose and glucose related structures (18). Increase in sialic acid content reduces the binding towards concanavalin A (23). The concanavalin A non-binding fraction of haptoglobin does not form complexes with haemoglobin (24), so the haemoglobin-binding capacity of haptoglobin is re-

\section{References}

1. Nieminen $\mathbf{M}$, Mattila $\mathbf{K}$, Vatonen V. Infection and inflammation as risk factors for myocardial infarction. Eur Heart J 1993; 14 Suppl K:12-6.

2. Langlois MR, Delanghe JR. Biological and clinical significance of haptoglobin polymorphism in humans. Clin Chem 1996; 42:1589-600.

3. Thomas L. Plasmaproteine und 'Passenger' Proteins. In: Thomas L, editor. Labor und Diagnose, 4th ed Marburg: Die Medizinische Verlagsgesellschaft, 1992:747-836.

4. Van Rijn H, Van der Wilt W, Stroes J, Schrijver J. Is the turbidimetric immunoassay of haptoglobin phenotype-dependent? Clin Biochem 1987; 20:245-8.

5. Andreassen A, Berg K, Torsvik H. Changes in Lp(a) lipoprotein and other plasma proteins during acute myocardial infarction. Clin Genet 1994; 46:410-6.

6. Boguschewski I, Mann D, Rohr A, Steinbruck U. Untersuchung der Haptoglobinserumkonzentration in der Akutphase des Myokardinfarktes mittels einfacher radialer Immundiffusion nach Mancini. Z Gesamte Inn Med 1981; 36:933-6.

7. Chapelle J-P, Albert A, Smeets J, Heusghem C, Kulbertus H. Effect of the haptoglobin phenotype on the size of a myocardial infarct. N Engl J Med 1982; 307:457-63.

8. Smith S, Bos G, Esseveld M, Van Eijk H, Gerbrandy J. Acute phase proteins from the liver and enzymes from myocardial infarction: a quantitative study. Clin Chim Acta 1977; 81:75-85

9. Anderson P, Eika C. Inhibition of thrombin-induced platelet aggregation by crude and highly purified $\alpha_{1}$-acid-glycoprotein. Scand J Haematol 1980; 25:202-4.

10. WHO Working groups. Evaluation of comprehensive rehabilitation and preventive programmes for patients after acute myocardial infarction. WHO Regional Office for Europe Copenhagen 1972:26-30.

11. Hørder M, Elser R, Gerhardt W, Mathieu M, Sampson E. J. IFCC methods for the measurement of catalytic concentration of enzymes. Part 7. IFCC method for creatine kinase (ATP: creatine N-phosphotransferase, EC 2.7.3.2) J IFCC 1989; 1:130-9; Eur J Clin Chem Clin Biochem 1991; 29:435-56.

12. Wicks R, Usategui-Gomez M, Miller M, Warshaw M. Immunochemical determination of CK-MB isoenzyme in human serum. II. An enzymatic approach. Clin Chem 1982; 28:54-8.

13. Roberts R, Henry P, Sobel B. An improved basis for enzymatic estimation of infarct size. Circulation 1975; 52:743-54.

14. Delanghe J, De Buyzere M, Cluyse L, Thierens H, Clement D. Acute myocardial infarction size and myoglobin release into serum. J Clin Chem Clin Biochem 1992; 30:823-80. duced during the early phase of acute myocardial infarction. Furthermore, recent findings postulate a role for haptoglobin in homing and trafficking of B lymphocytes (25).

The increased haptoglobin concentration in acute myocardial infarction upon admission, followed by a temporary decrease due to a limited haemolysis and the altered glycosylation of haptoglobin in acute myocardial infarction upon admission suggest an involvement of haptoglobin in the complex mechanism leading to acute myocardial infarction. Further studies will be needed to investigate the specificity of our findings and the interaction between haptoglobin and the complex mechanism leading to acute myocardial infarction.

\section{Acknowledgements}

We thank E. Dhondt, M. D. for clinical discussions.

15. Fink $P$, Römer $M$, Haeckel R, Fateh-Moghadam A, Delanghe J, Dubs R. Measurement of proteins with the Behring nephelometer. A multicentre evaluation. J Clin Chem Clin Biochem $1989 ; 27: 261-76$.

16. Whicher J, Ritchie R, Johnson A, Baudner S, Bienvenu J, Blirup-Jensen S, et al. A new international reference preparation for proteins in human serum (RPPHS). Clin Chem 1994; 40:934-8.

17. Smithies $\mathrm{O}$. Zone electrophoresis in starch gels: group variations in the serum proteins of normal human adults. Biochem J $1955 ; 61: 629-41$.

18. Delanghe J, De Buyzere M, De Scheerder I, Claeys L, Wieme R. Lectin-affinity chromatography of serum gamma-glutamyltransferase in liver disease. Clin Chim Acta 1987; 162:311-8.

19. Van Rijn H, Kruit W, Schrijver J. Haptoglobin typing, is it clinically necessary for a reliable determination of haptoglobin with the single radial immunodiffusion technique? J Clin Chem Clin Biochem 1994; 22:109-12.

20. Kindmark $C$. Sequential changes in plasma proteins in various acute diseases. In: Bianchi R, Mariani G, Mc Farlane AS, editors. Plasma protein turnover. New York: Mc Millan Press, 1976:395-402.

21. Chen H, Zhong G, Li L, Wang X, Zhou T, Chen Z. Effects of gender and age on thixotropic properties of whole blood from healthy adult subjects. Biorheology 1991; 28:177-83.

22. Van der Laarse A, Hermens W, Hollaar L, Jol M, Willems G, Lemmens $\mathrm{H}$, et al. Assessment of myocardial infarction by serial measurement of serum alpha-hydroxybutyrate dehydrogenase levels. Am Heart J 1984; 107:248-60.

23. Köttgen E, Bauer C, Reutter W, Gerok W. Neue Ergebnisse zur biologischen und medizinischen Bedeutung von Glycoproteinen. Klin Wochenschr 1979; 57:151-9.

24. Katnik I. Studies on haptoglobin binding to concanavalin A. Biochim Biophys Acta 1984; 790:8-14.

25. Hanasaki K, Powell L, Varki A. Binding of human sialoglycoproteins by the $\mathrm{B}$ cell specific lectin CD22. Selective recognition of immunoglobulin $\mathrm{M}$ and haptoglobin. $\mathrm{J}$ Biol Chem $1995 ; 270: 7543-50$.

\section{Received June 6/November 4, 1996}

Corresponding author: Prof. Dr. Joris R. Delanghe, Laboratorium Klinische Scheikunde, Universitair Ziekenhuis Gent, De Pintelaan 185, B-9000 Gent, Belgium 